\title{
LAJU KEMUNDURAN MUTU GONGGONG (Strombus sp.) REBUS PADA PENYIMPANAN SUHU CHILLING DAN RUANG DENGAN MUTU SENSORI
}

\author{
Rate of Decline Quality of Gonggong (Strombus sp.) Breaked on Chilling Temperature \\ Storage and Space with Sensory Quality
}

\author{
Vika Annur Syafitri ${ }^{1}$, Zubaidah Anjar Rezeki'1), Azwin Apriandi ${ }^{\left.{ }^{*}\right)}$ \\ 1)Program Studi Teknologi Hasil Perikanan, Fakultas Ilmu Kelautan dan Perikanan, \\ Universitas Maritim Raja Ali Haji
}

*Korespondensi : azwinapriandi@umrah.ac.id

Diterima 6 Oktober 2020; Disetujui 30 Oktober 2020

\begin{abstract}
This research was conducted to observe the rate of deterioration in the quality of boiled snails (Strombus sp.). Organoleptic is a method of sensory freshness determination. The speed at which a snail decomposed was primarily influenced by the temperature. This study aims to determine the best quality of barking snails stored at chilling and rooming temperatures. Samples of barking snails were taken from Tanjung Unggat water. This research method includes measuring the morphometric, yield, and organoleptic of the barking snail (Strombus sp.). The results showed that the use of chilling temperature could extend the shelf life of boiled barking snails, as evidenced by the high value of the organoleptic parameters compared to barking snails at room temperature storage, based on the organoleptic parameters of frozen clam meat based on SNI 3460.1-2009.
\end{abstract}

Key word: bark boiled snail, morphometric, organoleptic, yield

\begin{abstract}
ABSTRAK
Penelitian ini dilakukan untuk mengamati laju kemunduran mutu siput gonggong (Strombus sp.) rebus. Organoleptik merupakan salah satu metode penentuan kesegaran secara sensorik. Kecepatan siput gonggong membusuk terutama dipengaruhi suhu. Penelitian ini bertujuan untuk menentukan kualitas terbaik dari siput gonggong yang disimpen pada suhu chilling dan ruang. Sampel siput gonggong diambil diperairan Tanjung Unggat. Metode penelitian ini meliputi mengukur morfometrik, rendemen, dan organoleptik siput gonggong (Strombus sp.). Hasil penelitian menunjukkan penggunaan suhu chilling dapat memperpanjang masa simpan siput gonggong rebus, dibuktikan dengan tingginya nilai parameter organoleptik dibandingan dengan siput gonggong pada penyimpanan suhu ruang, berdasarkan parameter organoleptik daging kerang beku berdasarkan SNI 3460.1-2009.
\end{abstract}

Kata kunci : morfometrik, rendemen, siput gonggong rebus, uji organoleptik

\section{PENDAHULUAN}

Provinsi Kepulauan Riau merupakan salah satu Provinsi berbasis kepulauanyang memiliki luas daratan sebesar 4\% dan 96\% luas lautan. Dengan luas wilayah total $241.215 \mathrm{~km} 2$ dengan topografi yang terdiri dari gugusan pulau yang dipisahkan oleh lautan (BPS Provinsi Kepulaun Riau, 2012). 
Tanjungpinang adalah ibu kota Provinsi Kepulauan Riau yang memiliki wilayah pesisir yang luas. Banyaknya biota perairan yang ditemukan di Tanjungpinang, gonggong merupakan biota yang dijadikan ikon kuliner khas Tanjungpinang, sehingga para nelayan menjadi permintaan pasar untuk menyuplai ke restoran-restoran makanan lautdan industri olahan siput gonggong.

Siput gonggong (Strombus sp.) adalah sejenis siput laut yang bertubuh lunak dari fillum Mollusca.Katakteristik dari siput gonggong yaitu operkulum pipih panjang yang dapat digunakan sebagai alat gerak di atas pasir atau lumpur.Siput gonggong juga memiliki kulit yang keras dengangaris bulat pada cangkangnya dan memiliki variasi warna cangkang kekuningan ataukeemasan (Utami, 2012). Siput gonggong hidup di laut dangkal dan merupakan hewan yang tidak banyak bergerak (sessil) sehingga mudah untuk dieksploitasi.

\section{BAHAN DAN METODE}

\section{Waktu dan Tempat}

Studi ini dilakukan pada bulan Juli sampai Agustus 2020 di Fakultas IImu Kelautan dan Perikanan. Pengambilan sampel dilakukan di perairan Tanjung Unggat Kecamatan Bukit Bestari. Preparasi sampel dilakukan di Laboratorium Fakultas Ilmu Kelautan dan Perikanan Universitas Maritim Raja Ali Haji (UMRAH).

\section{Alat dan Bahan}

Alat yang digunakan saat preparasi adalah timbangan digital, penggaris 30 $\mathrm{cm}$, pisau, nampan alumunium, plastik. Alat yang digunakan untuk proses perebusan adalah panci dan pemanas. Bahan utama yang digunakan adalah siput gonggong (Strombus sp.) 30 sampel yang diperoleh dari perairan Tanjung Unggat Kota Tanjungpinang, air untuk perebusan.

\section{Metode Penelitian}

Studi ini terdiri atas dua tahap, yaitu tahap preparasi bahan baku, tahap organoleptik. Tahap organoleptik dilakukan dengan menggunakan suhu ruang dan chilling untuk melihat perbedaan laju kemunduran mutu terhadap gonggong (Strombus sp.) rebus.

\section{Prosedur Penelitian}

Studi ini dilakukan dalam beberapa tahapan yaitu, tahapan pertama meliputi pengambilan sampel siput gonggong (Strombus sp.) dari perairan pesisir Tanjung Unggat Kota Tanjungpinang. Selanjutnya tahapan kedua pencucian dan karakterisasi perhitungan morfometrik siput gonggong segar (Strombus sp.), tahapan ketiga preparasi sampel siput gonggong dengan suhu $85-95^{\circ} \mathrm{C}$ selama \pm 15 menit, tahapan keempat perhitungan setiap rendemen daging siput gonggong rebus, tahapan kelima amati kemunduran mutu siput gonggong (Strombus sp.) pada suhu chilling dan ruang.

\section{Pengambilan sampel dan Morfometri}

Pengambilan sampel siput gonggong (Strombus sp.) di perairan Tanjung Unggat Kota Tanjungpinang. Kemudian sampel di cuci bersih dan dilakukan pengukuran morfometrik antara lain panjang dan lebar siput gonggong.

\section{Preparasi Sampel}

Sampel gonggong utuh direbus sebanyak 30 ekor dengan penambahan air \pm 2 liter selama \pm 15 menit dengan suhu $85{ }^{\circ} \mathrm{C}-90{ }^{\circ} \mathrm{C}$ (Prasetyo et al. 2012). Preparasi pemisahan cangkang, daging dan jeroan gonggong rebus dan selanjutnya dilakukan perhitungan setiap rendemen (cangkang, daging, jeroan). Daging gonggong rebus kemudian 
dimasukkan kedalam kantong plastik clip, dan disimpan pada suhu chilling dan ruang amati kemunduran mutu gonggong.

\section{Perhitungan Rendemen}

Rendemen dihitung sebagai presentasi bobot bagian tubuh gonggong daribobot awal.Perhitungan rendemen daging gonggong rebus (daging, cangkang, jeroan) menggunakan rumus sebagai berikut:

Rendemen $(\%)=\frac{\text { Bobot contoh }(\mathrm{g})}{\text { Bobot total }} \times 100 \%$

\section{Uji Organoleptik / Sensori (BSN, 2009)}

Uji organoleptik merupakan cara pengujian yang bersifat subjektif menggunakan organ indera pada sampel. Pengujian organoleptik pada suhu chilling dilakukan dengan waktu 4 jam sekali pengamatan dan pada suhu ruang dilakukan pengamatan selama 1 jam sekali. Setiap perlakuan pengujian sebanyak 15 sampel. Pengujian organoleptik dilakukan untuk mengetahui perubahan yang terjadi pada sampel. Pengamatan dilakukan secara organoleptik menggunakan lembar penilaian sensori daging kerang beku berdasarkan SNI 3460.1-2009.

\section{HASIL DAN PEMBAHASAN}

\section{Morfometrik Gonggong}

Morfometri salah satu ciri yang berkaitan dengan ukuran tubuh gonggong misalnya panjang total dan panjang baku. Tiap spesies gonggong mempunyai ukuran mutlak yang berbeda-beda. Pengukuran morfometri dibutuhkan satuan yang digunakan dalam proses pengukuran, satuan ukur dinyatakan dalam satuan millimeter atau centimeter (Affandi et al.,1992).
Tabel 1. Hasil pengukuran dan bobot siput gonggong strombus sp.

\begin{tabular}{lr}
\hline Parameter & \multicolumn{1}{c}{ Nilai } \\
\hline panjang $(\mathrm{cm})$ & $7,03 \pm 0,41$ \\
lebar $(\mathrm{cm})$ & $4,55 \pm 0,37$ \\
berat Total (gram) & $37,86 \pm 5,17$ \\
\hline
\end{tabular}

Berdasarkan Tabel 1. dapat dilihat morfometrik gonggong memiliki panjang rata-rata $7,03 \pm 0,41 \mathrm{~cm}$, lebar $4,55 \pm$ $0,37 \mathrm{~cm}$, dan berat total $37,86 \pm 5,17$ gram. Perbedaan morfometrik tersebut dapat terjadi karena ukuran dan berat gonggong dipengaruhi oleh pertumbuhan, jenis kelamin, umur, makanan dan lingkungan yang mendukung untuk pertumbuhan.

\section{Rendemen Gonggong}

Rendemen merupakan persentase bagian bahan baku yang dapat dimanfaatkan. Semakin tinggi nilai rendemen, maka semakin tinggi pula nilai ekonomisnya sehingga pemanfaatannya dapat menjadi lebih efektif. Rendemen daging gonggong dihitung berdasarkan persentase perbandingan bobot contoh dan bobot total.

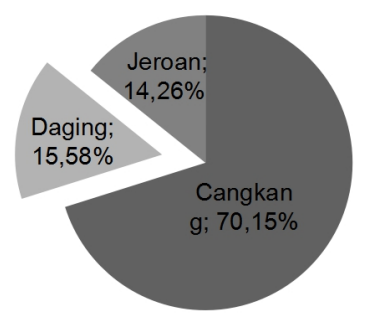

Gambar 2. Nilai rendemen siput gonggong

Berdasarkan Gambar 2. Dapat dilihat bahwa gonggong memiliki rendemen daging sebesar $15,58 \%$, jeroan sebesar $14,26 \%$, cangkang sebesar $70,15 \%$. Cangkang gonggong memiliki nilai persentase yang besar. Siput gonggong dengan ukuran bobot yang berbeda 
memiliki panjang tubuh serta proporsi tubuh yang berbeda pula.

\section{Kemunduran Mutu Gonggong}

Pengujian organoleptik merupakan salah satu metode untuk melihat kemunduran mutu siput gonggong. Metode ini bersifat subyektif, karena pengujian menggunakan panca indera manusia. Penetapan kemunduran mutu siput gonggong secara organoleptik dilakukan menggunakan score sheet yang telah ditetapkan oleh Badan Standardisasi Nasional SNI 3460.1-2009 (BSN 2009). Parameter yang diamati meliputi perubahan pada penampakan, aroma, rasa, dan tekstur. Pengamatan dilakukan dengan 2 perlakuan yaitu suhu chilling dan ruang. Dimana suhu chilling diamati 4 jam sekali selama 24 jam dan pada suhu ruang diamati 1 jam sekali selama 24 jam.

\section{Parameter Penampakan Suhu Chilling}

Nilai kenampakan siput gonggong rebus ditentukan oleh warna daging gonggong dan ada tidaknya cacat fisik pada gonggong tersebut. Gonggong dengan kondisi telah mengalami kemunduran mutu, akan tampak perubahan pada warna daging yang lebih kusam. Nilai kenampakan hasil penelitian pada penyimpanan suhu chilling di setiap jam memiliki nilai rata-rata 9 tidak terjadi kemunduran mutu (Gambar 3).

Berdasarkan Gambar 4. Dapat dilihat siput gonggong rebus mulai mengalami kemunduran mutu pada jam ke 6 hingga 24. Pada jam ke 6 dan 7 terjadi penurunan mutu dengan rata-rata 7,2 hingga 7,1. Jam ke 8 hingga 12 terjadi penurunan mutu namun ketahanan mutu tidak berubah setiap jam dengan rata-rata 7. Pada jam ke 13 hingga ke 22 laju kemunduran mutu terjadi dengan ratarata 6,4 hingga 5 . Siput gonggong rebus mengalami penurunan mutu yang signifikan pada jam 23 hingga 24 dengan nilai rata-rata 3,3 hingga 3 yang dispesifikasikan tidak utuh, cacat, daging berwarna keputih-putihan, kusam dan kotor. Kemunduran mutu siput gonggong rebus terjadi disebabkan oleh suhu penyimpanan yang tinggi.

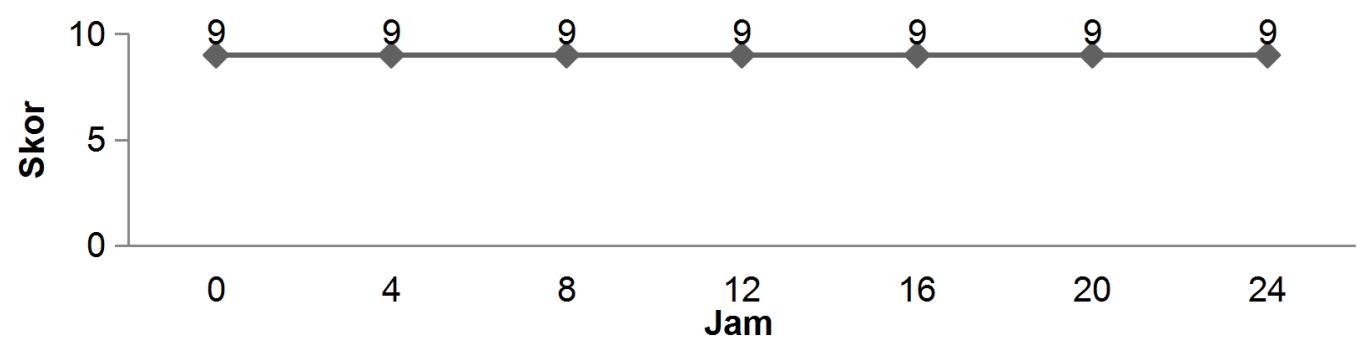

Gambar 3. Nilai Organoleptik Penampakan Siput Gonggong Rebus selama Penyimpanan Suhu Chilling

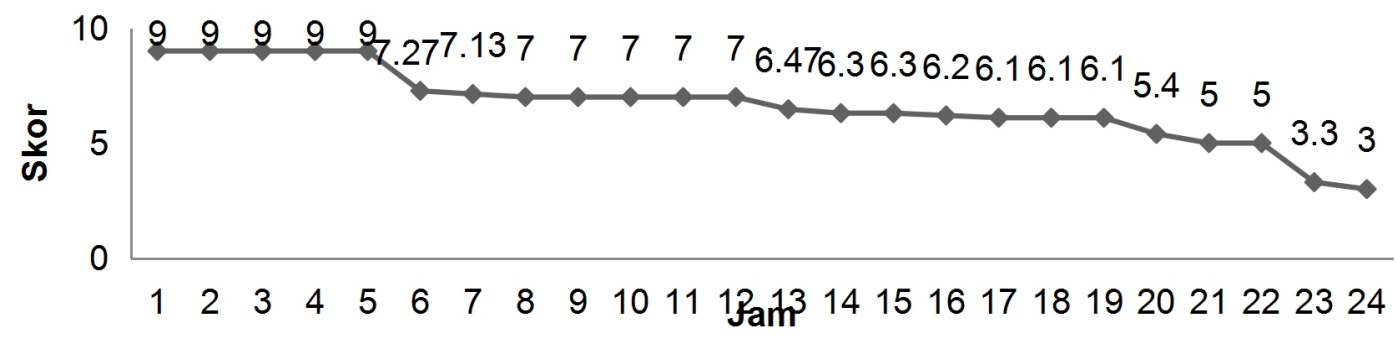

Gambar 4. Nilai Organoleptik Kenampakan Siput Gonggong Rebus selama Penyimpanan Suhu Ruang 
Suwetja (1990) yang menyatakan bahwa suhu penyimpanan hewan laut memegang peranan penting pada saat hewan tersebut mati, penggunaan suhu rendah dapat memperpanjang daya awet. Penentuan bahan pangan umumnya bergantung pada kenampakan yang dimiliki.

\section{Paramater Aroma \\ Suhu Chilling}

Bau atau aroma dinilai dari ketajaman baud aging gonggong segar serta ada tidaknya bau busuk atau bau amoniak. Siput gonggong memiliki aroma yang spesifik jika dalam keadaan segar. Melalui aroma juga dapat mengetahui tingkat kesegarannya. Jika siput gonggong sudah mengalami kemunduran mutu maka baunya muncul bau busuk disertai bau amoniak dan sedikit bau $\mathrm{H}_{2} \mathrm{~S}$. Hasil pengamatan laju kemunduran mutu siput gonggong berdasarkan bau dapat dilihat pada Gambar 5.
Berdasarkan hasil uji pengamatan bau siput gonggong rebus yang disimpan pada suhu chiliing selama 24 jam memiliki nilai rata-rata 9 sampai 7,9. Aroma siput gonggong selama penyimpanan memiliki bau yang masih sangat segar hingga di 20 jam namun pada saat di jam ke 24 daging mengalami penurunan.

Perubahan aroma yang terjadi disebabkan karena adanya penguraian protein pada gonggong akan menghasilkan senyawa trimetilamin dan amonia. Jika kesegaran gonggong mengalami penurunan, maka kandungan nitrogen yang mudah menguap akan mengalami peningkatan (Puspitasari 2012). Bau yang ditimbulkan pada siput gonggong diakibatkan terakumulasinnya basa-basa yang menguap hasil proses dekomposisi oleh mikroorganisme seperti senyawa-senyawa sulfur, alcohol aromatic (fenol,kresol), serta senyawasenyawa heterosiklik seperti indol dan skatol (Nurjanah et.al 2004).

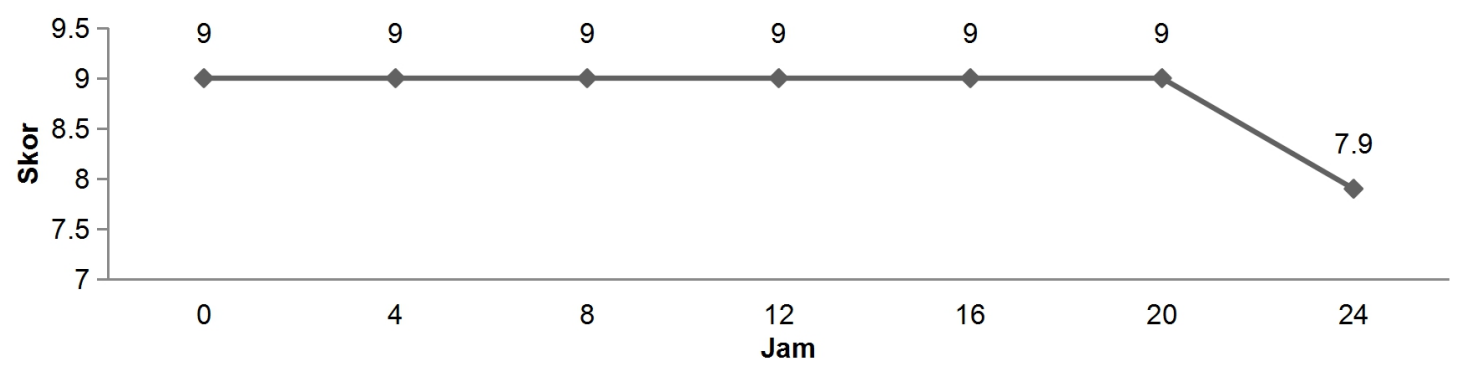

Gambar 5. Nilai Organoleptik Bau Siput Gonggong Rebus selama Penyimpanan Suhu Chilling

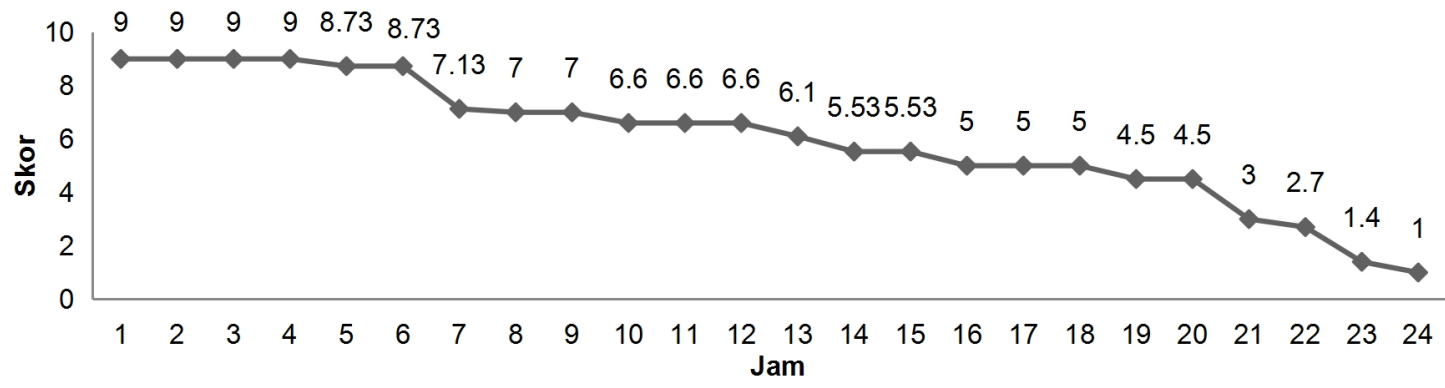

Gambar 6. Nilai Organoleptik Bau Siput Gonggong Rebus selama Penyimpanan Suhu Ruang 


\section{Suhu Ruang}

Berdasarkan hasil uji organoleptik parameter aroma siput gonggong rebus setelah disimpan pada suhu ruang selama 24 jam menunjukkan bahwa semakin lama penyimpanan maka semakin menurun aroma kesegaran dari siput gonggong rebus. Pada jam ke 1 hingga ke 4 siput gonggong masih memiliki aroma segar dengan nilai ratarata 9. Laju kemunduran mutu mulai terlihat pada jam ke 5 hingga ke 24. Pada jam ke 6 hingga 7 kemunduran mutu mulai terjadi dengan nilai rata-rata 8,7 . Jam ke 8 hingga 20 nilai rata-rata laju kemunduran mutu siput gonggong berkisar antara 7,1 hingga 4,5. Siput gonggong yang sudah mengalami kemunduran mutu maka muncul aroma busuk disertai bau amoniak dan sedikit bau $\mathrm{H}_{2} \mathrm{~S}$.

Dapat dilihat pada Gambar 6. bahwa pada jam ke 20 hingga 24 siput gonggong mengalami kemunduran mutu yang signifikan dengan nilai score sheet 3 sampai 1 yang dispesifikan dengan bau busuk nyata sekali. Menurut llyas (1983) bahwa, pembusukkan pada hewan laut lebih bersifat ketengikan oksidatif. Oksidasi lemak dapat menimbulkan bau tengik pada bahan pangan yang tidak diinginkan. Bau atau aroma sangat berperan terhadap kesukaan konsumen, jika aroma dari bahan pangan tidak sedap maka penilaian mutunya tidak bagus.

\section{Parameter Rasa \\ Suhu Chilling}

Rasa merupakan hal yang penting untuk menuntukan produk tersebut diterima oleh konsumen atau tidak. Setiap produk memiliki rasa spesifik yang berbeda tergantung dari bahan penyusunnya. Menurut Machmud et al. (2012), asam amino merupakan salah satu komponen pembentuk bau dan rasa. Asam amino yang terdapat pada protein gonggong dalam teknologi pangan dapat mempengaruhi rasa manis, hambar, bahkan pahit. Komponen penbentuk baud an rasa ditibulkan karena adanya kandungan asam amino pada bahan pangan. Asam amino yang terdapat pada protein gonggong dalam teknologi pangan mempengaruhi rasa manis, hambar, bahkan pahit. Produk perikanan seperti gonggong pada keadaan segar memiliki rasa yang manis dan rasa tersebut akan berubah ketika gonggong mengalami kebusukan.

Hasil analisis organoleptik gonggong rebus pada suhu chilling terjadi penurunan kemunduran mutu di jam 16 dan 20 dengan rata-rata 8,6 dan pada di jam ke 24 terjadi penurunan kembali dengan rata-rata 7,53. Hasil organoleptik pada rasa disajikan pada Gambar 7 .

Berdasarkan Gambar 8. dapat dilihat pada jam ke 1 sampai ke 4 siput gonggong memiliki rasa yang masih segar dengan nilai rata-rata 9. Pada jam ke 5 sampai ke 24 laju kemunduran mutu parameter rasa mulai terjadi. Pada jam ke 5 hingga 21 laju kemunduran mutu gonggong berkisar antara 7,9 higga 4,4. Penurunan mutu terendah terjadi pada jam ke 22 hingga 24 dengan rata-rata 3,6 hingga 1 yang dispesifikasikan pahit dan sepat. Rasa adalah faktor penting untuk menentukan kepuasan untuk menerima atau menolak suatu produk pangan oleh konsumen. Meskipun parameter lainnya baik, jika rasa tidak disukai maka produk akan ditolak. 


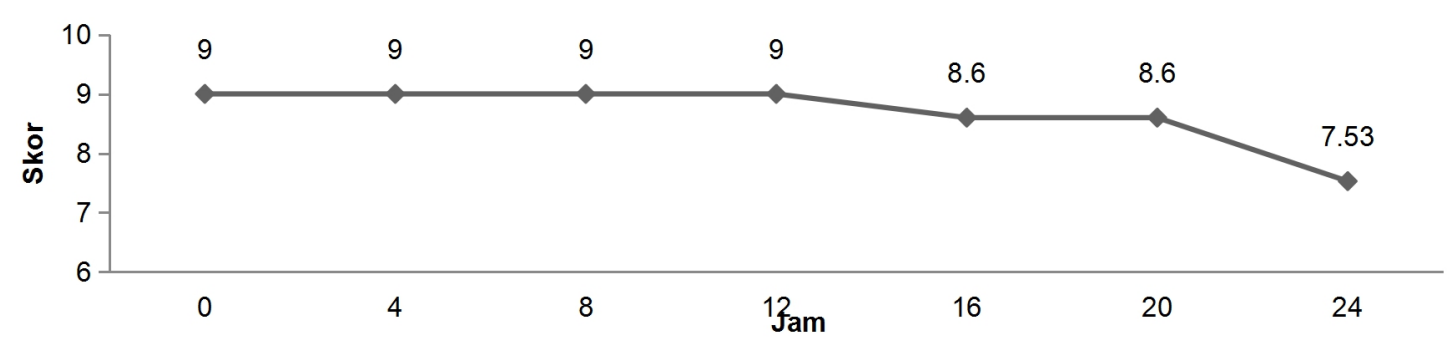

Gambar 7. Nilai Organoleptik Rasa Siput Gonggong Rebus selama Penyimpanan Suhu Chilling

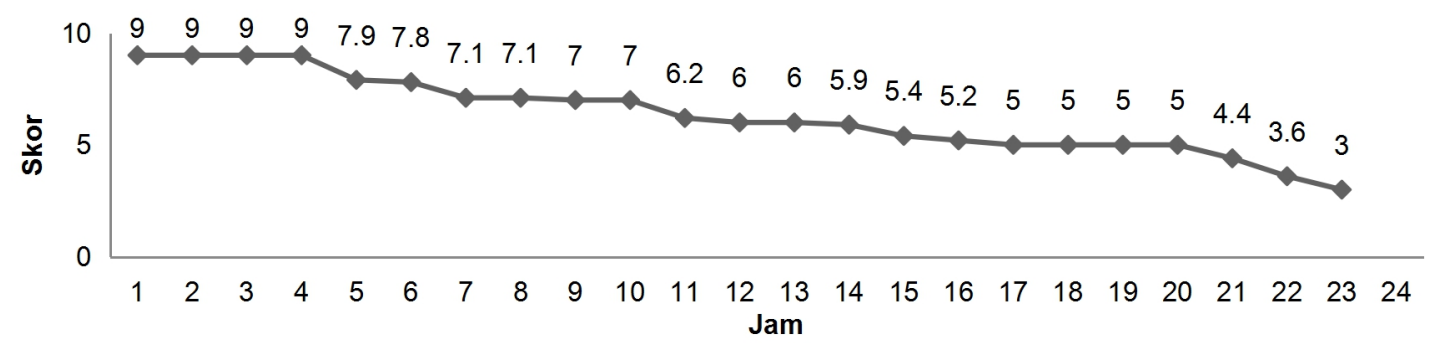

Gambar 8. Nilai Organoleptik Rasa Siput Gonggong Rebus selama Penyimpanan Suhu Ruang

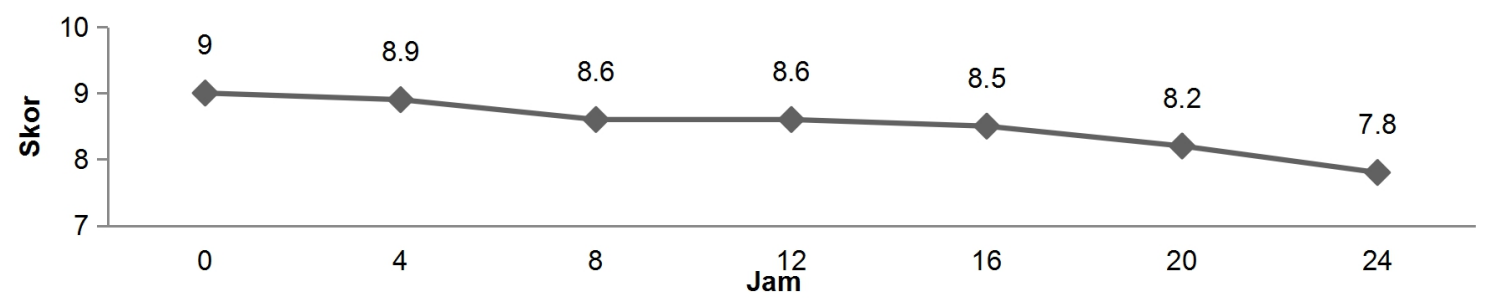

Gambar 9. Nilai Organoleptik Tekstur Siput Gonggong Rebus selama Penyimpanan Suhu Chilling

Parameter Tekstur

\section{Suhu Chilling}

Berdasarkan pada Gambar 9 dapat diketahui tekstur gonggong rebus mengalamai kemunduran mutu yang signifikan. Pada awal penyimpanan, nilai tekstur gonggong rebus pada penyimpanan suhu chilling berkisar 9 dengan deskripsi elastis, kompak dan padat. Pada akhir penyimpanan, nilai tekstur daging gonggong rebus menurun hingga berkisar 7,8 dengan deskripsi elastis, kompak dan kurang dapat.

Pada saat gonggong mati, $\mathrm{pH}$ tubuh gonggong akan menurun. Menurunya $\mathrm{pH}$ dapat mengakibatkan enzim yang bekerja pada suhu rendah menjadi aktif. Katepsin, yaitu enzim proteolitik yang berfungsi mengurai protein menjadi senyawa sederhana, merombak struktur jaringan protein otot menjadi lebih longgar yang mengakibatkan daging gonggong menjadi agak lunak. Proses perombakan oleh enzim disebut dengan autolisis (Diniah et al 2006). Gonggong yang mengalami autolisis memiliki tekstur yang tidak elastis, sehingga apabila dagingnya ditekan dengan jari akan membutuhkan waktu relatif lama untuk kembali kekeadaan semula. Jika proses autolisis sudah terjadi, maka daging yang ditekan tidak pernah kembali ke posisi awal (Sumardi, 2010).

\section{Suhu Ruang}

Berdasarkan hasil uji organoleptik parameter tekstur siput gonggong rebus setelah disimpan pada suhu ruang 
selama 24 jam menunjukkan bahwa semakin lama penyimpanan maka tekstur akan mengalami penurunan. Parameter tekstur merupakan parameter yang memiliki ketahanan cukup baik dengan rata-rata 9 sampai 3 .

Pada jam ke 1 sampai ke 7 tekstur memiliki rata-rata tertinggi yaitu 9 yang dispesifikasikan elastis, kompak dan padat. Laju kemunduran mutu parameter tekstur mulai terjadi pada jam ke 8 hingga ke 24. Pada jam ke 8 hingga 20 kemunduran mutu gonggong rebus memiliki rata-rata 8,6 hingga 6,1 nilai tersebut masih tergolong baik. Pada jam ke 21 hingga 22 nilai rata-rata menurun yaitu 5,8 hingga 5,6. Kemunduran mutu terendah terjadi pada jam ke 23 hingga 24 dengan rata-rata 3,9 hingga 3 yang dispesifikasikan lunak dan sedikit hancur. Daging gonggong yang mengalami autolisis memiliki tekstur yang tidak elastis.Autolisis adalah proses perombakan sendiri, yaitu proses perombakan jaringan oleh enzim yang berasal dari produk perikanan tersebut (Nurjannah, 2004).

\section{KESIMPULAN}

Berdasarkan hasil penelitian morfometrik gonggong yaitu, rata-rata berat utuh gonggong 37,86 gram, panjang 7,03 gram, dan lebar 4,55 gram. Rendemen gonggong terdiri dari cangkang, daging, dan jeroan. Berdasarkan hasil penelitian cangkang merupakan bagian paling besar yaitu sebesar $70,15 \%$, sedangkan jeroan merupakan bagian terkecil yaitu sebesar $14,26 \%$ dan rendemen daging $15,58 \%$.

Pada laju kemunduran mutu, gonggong rebus pada penyimpanan suhu chilling proses kemunduran mutu terjadi sangat lama karena pada penyimpanan suhu chilling proses prombakan bakteri terjadi sangat lambat sedangkan pada suhu ruang laju kemunduran mutu gonggong rebus lebih cepat dikarenakan pada suhu ruang aktivitas enzim dan bakteri lebih cepat berkembang.

\section{DAFTAR PUSTAKA}

Adawiyah, Rabiatul. 2002. Pengolahan Pengawetan Ikan. Jakarta: PT. Bumi Aksara.

Affandi R, Sjafei DS, Rahardjo MF, \& Sulistiono. Iktiologi. Suatu Pedoman Kerja Laboratorium. Departemen Pendidikan dan Kebudayaan. Direktorat Jenderal Pendidikan Tinggi. Pusat Antar Universitas IImu Hayat. Bogor : Institut Pertanian Bogor, 1992.

[BSN] Badan Standardisasi Nasional. 2009. Daging Kerang Beku SNI 3460.1:2009. Jakarta (ID): Badan Standardisasi Nasional.

Diniah, Lismawati, D., Martasuganda, S. 2006. Uji Coba Dua Jenis Bubu Penangkap Keong Macan Di Perairan Karang Serang Kabupaten Tanggerang. Jurnal Mangrove dan Pesisir Vol. VI No.2/2006.

llyas, S. 1983. Teknologi Refrigasi Hasil Perikanan. Teknik Pendinginan Ikan. Paripurna. Jakarta.

Machmud, N. F., N. Kurniawati dan K. Haetami. 2012. Pengkayaan Protein dari Surimi Lele Dumbo Pada Brownies Terhadap Tingkat Kesukaan. Jurnal Perikanan dan Kelautan, 3 (3) : 183-191.

Nurhayati, T., E. Salamah, K. Tampubolon, dan A. Apriland. 2011 Peranan inhibitor katepsin dari ikan patin (Pangasius hyphopthalmus) untuk menghambat kemunduran 
mutu ikan bandeng (Chanos chanos Forskal). JPHPIXIV, (1):49-55.

Nurjannah, S., Sukarno, M., Muldani. 2004. Teknik Penanganan Ikan Basah di Kapal, PPI,dan Tempat Pengolahan. Buletin THP. VIII (1).

Prasetyo, Eko., Patriadi, M,A,N., Swastike, W. 2012. Pengaruh lama Perebusan

terhadap Kualitas Kimia dan Organoleptik Abon dari Bagian Dada dan pada Ayam Petelur aktif. Jurnal Sains Pertenakan, 10(2): 108-114.

Puspitasari, Y.E. (2012) Trimetilamin Oksida (Kajian pada Ikan Segar dan Ikan Beku). Fakultas Perikanan dan IImu Kelautan Malang: Univ. Brawijaya.

Sanger, G. 2010. Mutu Kesegaran Ikan Tongkol (Auxic tazard) Selama Penyimpanan Suhu Dingin. Jurnal Warta Wiptek. 35: 39-43
Sumardi, J, A. 2010. Ikan Segar Mutu dan Cara Pendinginan. Malang: Universitas Brawijaya.

Suwetja, I, K. 1990. Penentuan Kesegaran Beberapa Jenis Ikan Dengan HPLC. Jurnal Fakultas Perikanan. 1(3):262-263.

Syari, I, A. 2005. Asosiasi Gastropoda di Ekosistem Padang Lamun PerairanPulau Lepar Provinsi Kepulauan Bangka Belitung. [Skripsi]. Institut Pertanian Bogor.

Utami, D, K. 2012. Studi Bioekologi Habitat Siput Gonggong (S. turturella) di Desa Bakit Teluk Klabat Kabupaten Bangka Barat Provinsi Kepulauan Bangka Belitung.[Skripsi]. Institut Pertanian Bogor.

Widiastuti, I, M. 2007.Sanitasi dan Mutu Kesegaran Ikan Konsumsi pada Pasar Tradisional di Kotamadya Palu. Jurnal Agroland, 14 (1): 77-81. 